\title{
The fight against terrorism and SC Resolution 2249 (2015): towards a more Hobbesian or a more Kantian International Society?
}

\author{
Peter Hilpold
}

Published online: 20 June 2016

(C) The Author(s) 2016. This article is published with open access at Springerlink.com

\begin{abstract}
Security Council Resolution 2249 of 20 November 2015 was intended to open a new chapter in the fight against terrorism in general and against ISIS in particular. However, in academia this Resolution was received with criticism. After an analysis of SC Resolution 2249, it will be argued that the criteria developed for assessing jus ad bellum in inter-state relations are of no easy application in the relationship between states and nonstate actors and in particular in regard to terrorists. If the prohibition of the use of force applies at all, this has to happen in a largely modified way. Fears that a lowered threshold for the use of force against terrorists will introduce a new "Hobbesian" element in international law do not appear to be justified. On the contrary, an international community showing more solidarity in the fight against terrorism will reinforce their Kantian traits. Resolution 2249 can offer an important contribution for such a development to take place.
\end{abstract}

Keywords Terrorism - Self-defence $\cdot$ jus ad bellum - Use of force $\cdot$ UN law $\cdot$ Kantian society · ISIS

\section{Introduction}

There are few United Nations Security Council (UNSC) Resolutions that received so much public attention as did the Resolution 2249 of 20 November 2015 on the fight against the Islamic State. ${ }^{1}$ At the political

\footnotetext{
${ }^{1}$ In the following, the most common abbreviation for the Islamic State, ISIS shall be used. Resolution 2249 refers to the Islamic State in Iraq and the Levant (ISIL, also known as Da'esh). See, UN Doc S/RES/ $2259(2015)<$ http://www.un.org/en/sc/documents/resolutions/2015.shtml>.
}

Peter Hilpold is Professor of Law at the University of Innsbruck. 
level this Resolution became the focal point for a series of initiatives to "redouble and coordinate" ${ }^{2}$ the efforts to fight ISIS. At the academic level, however, immediately after this document was issued, an intense debate concerning a series of pivotal concepts of international law set in. ${ }^{3}$ This short but fierce controversy has immediately revealed that the struggle against terrorism has all the ingredients to put into doubt convictions on issues of international law that seemed to be widely uncontested not far ago. In other cases ongoing legal developments have been accelerated.

While UNSC Resolution 2249 was considered by many lawyers as vague it is argued here that this Resolution can be seen as an important clarifying instrument not only with regard to the limits of forceful action against terrorism. It will be argued that the criteria for the use of force developed for the interstate context only partly apply to the field of international anti-terrorism law. As for the rest, far-reaching adaptions are needed. More fundamentally, UNSC Resolution 2499 raises the question as to where international law is headed. Are we regressing to a Hobbesian international legal order under the pressure of ever more violent terrorist attacks that compel us to take recourse to force? Not long ago a Kantian age of international peace seemed to be at arm's length. In this paper, it will be argued that UNSC Resolution 2249, notwithstanding the licence to take recourse to force it furnishes, represents no reversal towards a Hobbesian order. There can be no doubt that terrorism and terrorist threats are an enormous challenge for modern international society. Nevertheless, if engaged in proper ways, this challenge can offer the international legal community the opportunity to become even more resilient and peaceful.

\section{Framing the issue: SC Resolution 2249}

In the immediate aftermath of its adoption, UNSC Resolution 2249 has been presented in two different ways: some portrayed it as an awkward example of a political compromise, an exercise in "constructive

\footnotetext{
${ }^{2}$ Ibid [5].

${ }^{3}$ Among the first academic contributions, see the postings on EJIL Talk by D Akande \& M Milanovic, The Constructive Ambiguity of the Security Council's ISIS Resolution <http://www.ejiltalk.org/theconstructive-ambiguity-of-the-security-councils-isis-resolution> and M Weller, Permanent Imminence of Armed Attacks: Resolution 2249 (2015) and the Right to Self-Defence Against Designated Terrorist Groups $<$ http:/ / www.ejiltalk.org/permanent-imminence-of-armed-attacks-resolution-2249-2015-and-the-right-toself-defence-against-designated-terrorist-groups $>$.
} 
ambiguity" ${ }^{4}$ legitimizing the options taken by major stakeholders involved in the Syrian conflict. For others, this Resolution has to be read in a self-defence perspective even though this document does not explicitly mention this concept. According to this latter position, UNSC Resolution 2249 gives authoritative clarification as to the factual and legal situation ISIL terrorism has created. ${ }^{5}$ The situation resulting from these attacks would give life to a right to individual and collective selfdefence according to Article 51 of the UN Charter.

It is contended here that the propositions mentioned above, while making some good points, do not do full justice to this Resolution. UNSC Resolution 2249 has to be read in a broader perspective, both with regard to the Security Council's attitude towards the use of force in general as with regard to the United Nations' fight against terrorism. It is argued here that UNSC Resolution 2249 is but a logical step in the Security Council's history of law interpretation and lawmaking in this area. ${ }^{6}$ Far from obfuscating the legal situation, this Resolution lends more clarity to processes initiated long before. UNSC Resolution 2249 is part of a long array of Security Council Resolutions dealing with terrorism ${ }^{7}$ and here it stands out for the contribution it makes to further clarify the attitude of international law as to this phenomenon.

A look at the features of UNSC Resolution 2249 offers the following salient elements. First of all, among all terrorist groups constituting a major challenge on a regional or a global scale, ISIS is singled out as a 'global and unprecedented threat to international peace and security,' a qualification so far no terrorist group has ever been awarded. The AlNusrah Front (ANF) and all other individuals, groups, undertakings and entities associated with Al-Qaida are also considered to constitute a

\footnotetext{
${ }^{4}$ See, Akande $\&$ Milanovic, supra note 3. For the notion of "constructive ambiguity" with regard to SC Resolutions, see extensively Security Council Report, Special Research Report No. 1: Security Council Action Under Chapter VII: Myths and Realities <http://www.securitycouncilreport.org/special-researchreport/lookup-c-glKWLeMTIsG-b-4202671.php>. The notion of "constructive ambiguity" as such is sometimes credited to Henry Kissinger, see, <https://en.wikipedia.org/wiki/Constructive_ambiguity> (6 December 2015). Mitt \& Bibi, Diplomacy as Demolition Derby, The New York Times, (13 September 2012). In reality, however, this concept is much older as it refers to the concept of "dilatorischer Formelkompromiss" coined by Carl Schmitt.

5 Weller, supra note 3 .

${ }^{6}$ It is generally contended that SC Resolutions are often ambiguous and of difficult interpretation due to the uneasy political compromise they regularly reflect. See, L Moir, Reappraising the Resort to Force: international Law, Jus ad Bellum and the War on Terror (Hart Publishing, Oxford, 2010) 36 for a different interpretation.

${ }^{7}$ For an overview on the main Resolutions on counter-terrorism so far passed by the SC, see the homepage by the SC Counter-Terrorism Committee <http://www.un.org/en/sc/ctc/resources/res-sc. html>.
} 
threat to international peace and security but UNSC Resolution 2249 clearly pinpoints ISIS as the major challenge. Being a "global and unprecedented" threat to international peace and security ISIS requires primary attention. ${ }^{8}$

The UN Security Council gives an assessment of the threat resulting from ISIS and dares a projection of its future development. This outlook is scary when the Security Council in paragraph 1 of the Resolution's operative part notes that ISIS 'has the capability and intention to carry out further attacks'. It refers to 'all such acts of terrorism as a threat to peace and security.' In what follows, this paper will examine whether this outlook undertaken by an authoritative institution has also legal implications.

Probably the most important provision is to be found in paragraph 5 in which all Member States that have the capacity to do so are called upon to take all necessary measures 'to redouble and coordinate their efforts to prevent and suppress terrorist acts committed by ISIS' as well as Al Qaeda and other terrorist groups designated or to be designated by the UN. Paragraph 5 is, however, as a whole not an easy read and pivotal provisions are strongly qualified.

First of all, only those Member States are called upon to take all necessary measures that "have the capacity to do so". A lack of capacity may relate primarily to the material (military or financial) level but it may also be of a legal or political nature 9 . At a first sight, this qualification is very broad and might provide a facile excuse for non-participation. In reality, however, a strict reading of this qualification might be more appropriate to intent and structure of this Resolution. In fact, Resolution 2249 leaves no doubt as to the extraordinary challenge ISIS terror poses and therefore no easy escape clause can be provided in face of such a threat. It is rather to be assumed that this qualification allows to "graduate" the various contributions. While there may be countries unable to provide any assistance in this fight the vast part of countries will be able to give at least some contribution. In sum, this qualification only emphasizes the aspect of solidarity: Assistance has to be given but in this due consideration can be paid to the actual possibilities of the single Member State.

\footnotetext{
${ }^{8}$ UNSC Resolution 2249 seems to re-comprise all these terrorist movements under the label of "unprecedented threats" but history, wording and structure of this Resolution make clear that the threat stemming from ISIS was the main cause and target of this act.

${ }^{9}$ Constitutions of single Member States may prohibit foreign military intervention. A special case is that of neutral States. In particular in Austria an intense discussion is taking place whether this country is allowed (or even required) to participate in such interventions. For some, Austria's position as a "permanently neutral State", a position acquired in 1955, stands in the way of such an intervention. However, as shown elsewhere, the concept of neutrality, Austria's government is sticking to, has no real foundation in international Law. If at all, it is of a political nature. See generally, P Hilpold, Solidarität und Neutralität (Nomos, Baden-Baden, 2010).
} 
The efforts to prevent and suppress terrorist acts committed by ISIS and other terrorist groups have to be "redoubled and coordinated", but only "on the territory under control of ISIL in Syria and in Iraq". Therefore, this Resolution does not envisage measures for the whole territory of Syria or Iraq and even less measures that should take place outside these states. As is well-known, in the meantime ISIS has bases in several countries. Before Syria, it was in Iraq, its first breeding nest, and afterwards it sprang to several other countries, in particular to Libya, a "failed state" where it build up a larger stronghold. Resolution 2249 does not deal with these situations and even less does it provide a basis for regime change in Syria.

Finally the question has to be addressed which measures the SC had in mind when drafting para. 5 of Resolution 2249. Efforts to "prevent and suppress" terrorist acts may call to mind "sting operations" and singular preventive measures to counter terrorist acts not really dissimilar to those executed also in other countries with stronger ISIS and Al Qaeda presence such as Yemen. The wording used in the last clause of para. 5 "and to eradicate the safe haven they have established over significant parts of Iraq and Syria" hints, however, at stronger measures implying the use of a larger scale of force. We are here no longer in the realm of "police action" but it comes clear that such operations have to be of a genuine military nature.

\section{Does Resolution 2249 open the way for the use of force under Chapter VII of the UN Charter?}

The foremost question Resolution 2249 raises is whether this document opens the way for the use of force under Chapter VII of the UN Charter. On this subject, Resolution 2249 lacks in final determination. However, a look at Security Council deliberations since the founding of the UN reveals that this attitude is not new but common practice. UNSC Resolution 2249 fits very well in the long series of Security Council resolutions on Chapter VII, the most important exception to the prohibition of the use of force. Resolution 2249 may therefore be innovative partly in its wording and in its overall structure, yet it is very traditional in its vagueness.

As is well-known, the procedure envisaged by Chapter VII for the activation of the peace enforcement system has never come to life as Member States were not prepared to make available armed troops to 
the Security Council on the basis of specific agreements as set forth in Article 43 of the UN Charter . ${ }^{10}$ The "principal" (or centralized) model, whereby the UN should directly enforce peace by its own troops should be replaced by the "agent" (or decentralized) model according to which the UNSC should only provide an "authorization" for the use of force carried out by Member States.

Originally this model was heavily criticized as a violation of the UN Charter, ${ }^{11}$ but today it seems to have acquired a customary law status due to its wide acceptance. ${ }^{12}$ This fact reveals that the provisions of the Charter are not to be seen rigidly, but suited for further development according to the needs in practice. The qualification coined for the European Convention of Human Rights as a "living instrument" ${ }^{13}$ can therefore be transposed also to the UN Charter. This seems all the more true if we consider that the respective provisions pertain to the cornerstone of the whole UN law, ${ }^{14}$ the prohibition of the use of force and its exceptions, and are therefore particularly delicate.

The delicacy of this question finds expression, first of all, in the need to circumscribe the delegated powers. Unfortunately, both the difficulties met in the consensus finding process within the UNSC as well as the impossibility to anticipate all possible developments on the ground and the ensuing need to adapt action, to a certain extent, to the factual situation encountered, require a certain amount of flexibility when implementing the authorization. This flexibility, of course, ought to have its limits and according to widespread opinion, often voiced in literature, these limits have been violated on the occasion of the enforcement of the no-fly-zones in Iraq. When UNSC Resolution 1973 of 2011 on the implementation of a no-fly-zone in Libya became de facto

\footnotetext{
${ }^{10}$ As is well known, the ICJ has qualified measures taken under Chapter VII as "enforcement measures." See, Certain Expenses, Advisory Opinion [1962] ICJ Rep 164.

11 This was in particular the case in the early 1990s when the authorization model, starting with SC Resolution 678 (1990) on Kuwait, found full-scale application. On this discussion, see, N Blokker, Is the Authorization Authorized? Powers and Practice of the UN Security Council to Authorize the Use of Force by "Coalitions of the Able and Willing," 11 Euro J Intl L (2000) 541; E Cannizzaro, Diritto Internazionale, $2^{\text {nd }}$ edn (G Giappichelli Editore, Torino, 2012) 76; B Conforti \& C Focarelli, Le Nazioni Unite, (CEDAM, 2012) 274; H Freudenschuß, Between Unilateralism and Collective Security: Authorization of the Use of Force by the Security Council, 5 Euro J Intl L (1994) 492, 522 where he stated, 'a new instrument has been created out of the need to fill the gap between the invocation of an inapplicable or inopportune right to collective selfdefence and the unwanted application of the system of collective security.'

12 See, the World Summit Outcome Document, UNGA Resolution 60/1 of 16 September 2005, reaffirming at [79] 'the authority of the Security Council to mandate coercive action'.

${ }^{13}$ See, the famous statement in Tyrer $v$ United Kingdom, Application no 5856/72, Series A, no 26 (25 April 1978) section 31

${ }^{14}$ See, Armed Activities on the Territory of the Congo (Democratic Republic of the Congo v Uganda) Merits [2005] ICJ Rep 168 [148].
} 
the basis for implementing regime change, nowhere allowed by this Resolution, the need to limit flexibility became even clearer. ${ }^{15}$ It was in particular this latter Resolution that evidenced how the UNSC loses control over enforcement once this power is delegated according to the decentralization model. ${ }^{16}$ The UNSC's appalling lethargy in the Syrian case can be attributed to a considerable extent to the shortcomings of the enforcement process in the Libyan case.

Assuming however that the problem of the extent and the limits of the delegation can be handled, the prior problem of just what elements the "authorization" model presupposes remains. Unfortunately, the UNSC practice is less than clear on this issue. According to a strict, orthodox approach, the following elements have to be given for a Security Council authorization to be fully in conformity with the Charter:

- a determination in accordance with Article 39 relating to the existence of any threat to the peace, breach of the peace or act of aggression;

- the chapeau "acting under Chapter VII" and

- an operative paragraph containing a "decision" to authorise Member States to use force. ${ }^{1}$

There can be no doubt, however, that a strict reading of these requirements would not do justice to the complexities of decision taking and law-making within UNSC. It is rather the case that the overall context has to be given primary attention, ${ }^{18}$ balancing this subjective

\footnotetext{
${ }^{15}$ See, PD Williams \& AJ Williams, Principles, Politics, and Prudence: Libya, the Responsibility to Protect, and the Use of Military Force, 18 Global Governance (2012) 273; N Ronzitti, NATO's Intervention in Libya: A Genuine Action to Protect a Civilian Population in Mortal Danger or an Intervention aimed at Regime Change? 21 Italian Yrbk Intl L (2011) 3; C Burke, Beyond Libya: Norms in International Law and the Use of Force by States, 21 Italian Yrbk Intl L (2011) 111.

${ }^{16}$ See, M Payandeh, The United Nations, Military Intervention, and Regime Change in Libya, 52 Virginia J Intl L (2012) 355 .

17 See Security Council Rep No 1, 26. According to this Report, in recent times, authorizing Resolutions have consistently included these elements.

18 'The language of a resolution of the Security Council should be carefully analysed before a conclusion can be made as to its binding effect. In view of the nature of the powers under Article 25, the question whether they have been in fact exercised is to be determined in each case, having regard to the terms of the resolution to be interpreted, the discussions leading to it, the Charter provisions invoked and, in general, all circumstances that might assist in determining the legal consequences of the resolution of the Security Council.' Legal Consequences for States of the Continued Presence of South Africa in Namibia (South West Africa) notwithstanding Security Council Resolution 276 (1970), Advisory Opinion [1971] ICJ Rep 16 [53].

See also, M Wood, The Interpretation of Security Council Resolutions, 2 Max Planck Yrbk UN L (1998) 73 'The terms of a resolution are to be interpreted "in their context".'
} 
criterion with the requirement of appropriate formal substance so as to give due respect to bona fides relying heavily on form and transparency. First of all, it can hardly be argued that the authorization regime should presently be the only key to use force according to Chapter VII of the Charter. It is true that the UNSC has not given any explicit authorization to use force in this case; the verb "to authorize" is not used in this document. Nonetheless, in the decisive paragraph 5 of UNSC Resolution 2249 Member States are "called upon" (to take all necessary measures) and it can be argued that thereby an even broader gate for the use of force is opened. In fact, by an "authorization" the principal (the Security Council) permits the agents (Member States) to act. Here, these are the Member States who require the permission to act. If a "call" is issued it is the principal who becomes active in the first place requiring the agents to act subsequently.

This is not a somewhat reluctantly given permission to act; in fact the Member States are summoned to do so. "To call upon" is more of an imperative act than a permissive one. Behind the "call" there is far more impetus than behind an "authorization." It could be argued that here the use of force is not permitted but required. Of course, reference to the general use of language cannot give an exhaustive answer for the interpretation of UN norms and acts. ${ }^{19}$ Of primary importance is rather the meaning resulting from the UN practice itself, the way UNSC understands this term in dialogue with the Member State. The relevant practice of the UNSC has therefore to be taken into consideration in order to see how this concept has been employed. Such an enquiry reveals that "calls" have in fact been issued to prompt States to intervene with armed force. ${ }^{20}$ "To call upon" is not much dissimilar from "to require" and in fact also this latter term has been used while adopting binding Chapter VII resolutions even without making any explicit reference to this Chapter. ${ }^{21}$

The resolution that perhaps comes closest in this approach to UNSC Resolution 2249 is Resolution 221 of 9 April 1966 by which the UN Security Council tried to make effective an earlier embargo against Southern Rhodesia governed by the illegitimate white apartheid regime

\footnotetext{
19 As is well known, according to Article 31 of the Vienna Convention on the Law of Treaties (VCLT) the "ordinary meaning" of a term is the starting point of the interpretation process. While the VCLT is not directly applicable on UN secondary law it can be argued that a similar approach has to be adopted also in this field, out of considerations of pragmatism and reasonableness.

${ }^{20}$ Similar considerations can be made with regard to the term "endorses" (see Security Council Report no $1,14)$, but it can be argued that this term is far closer to "to authorize" than it is the case for "to call upon."

${ }^{21}$ See, Security Council Res 1695 of 15 July 2006 (also cited in SC Report no 1, 15). This Resolution was intended to prevent North Korea from acquiring nuclear capabilities.
} 
under Ian Smith. At issue was an enforcement of an oil embargo. A private oil company wanted to bypass the embargo that the United Kingdom, possibly in collaboration with Portugal, wanted to stop. In this situation Portugal, the colonial power responsible for the territory of Mozambique from where the oil could be pumped to Southern Rhodesia, was called upon not to receive oil destined for Southern Rhodesia at the port of Beira (Mozambique) while a further call was directed to the United Kingdom attributing respective enforcement powers to this state. This Resolution therefore created both negative obligations (obligation to desist) and positive obligations (obligation to act) as it also mentioned explicitly the subjects of these obligations. This specific reference to single addressees of the various obligations contained in Resolution 221 makes clear, however, that the similarities with UNSC Resolution 2249 must not be overemphasized. In fact, no such specific reference can be found in this latter resolution which addresses the Member States in their entirety with the sole limitation referring to "capacity."

Alongside UNSC Resolution 221 of 1966, UNSC Resolution 83 of 27 June 1950 could be mentioned as a predecessor model for UNSC Resolution 2249. UNSC Resolution 83 was the first ever considered to implement the authorization model. It was issued after the attack by North Korea against South Korea and it recommended that Member States provide assistance to the Republic of Korea 'as may be necessary to repel the armed attack and restore international peace and security in the area.' In this case the addressees of the resolution are all the Member States.

Nonetheless, notable differences with regard to Resolution 2249 remain. In fact, notwithstanding the open formulation there was little doubt which states were considered for a military intervention in Korea. With regard to UNSC Resolution 2249 this is by far not so evident. Indeed, while UNSC Resolution 83/1950 was more or less clear as to which states had to participate in the intervention, UNSC Resolution 2249 is not as clear.

Thus, at this point, it is not fully evident whether the formula "calls upon" in UNSC Resolution 2249 legitimizes the use of force according to Chapter VII of the Charter in a way similar to the "authorization" model; no directly corresponding UN practice can be discerned. The UNSC has confirmed the existence of a qualified ("global and unprecedented") "threat to the peace" (a direct reference to Article 39 of the Charter) and called upon Member States, at least those capable to 
do so, to "take all necessary measures," thereby implicitly referring to Article 42 of the Charter. So, Chapter VII is touched upon twice without being mentioned explicitly. There can be no doubt that these ambiguities and complexities pertain directly to the enemy that here comes into play, which, despite its name, is not a state but a terrorist group. Should this lead to a totally different reading of Resolution 2249, a reading in terms of self-defence and therefore in line with UNSC Resolution 1368 (2001)? Some have suggested so. ${ }^{22}$ This calls for a closer examination of the relationship between the right to self-defence and the fight against terrorism in international law.

\section{UNSC Resolution 2249 and the right to self-defence}

At first sight it appears to be difficult to read UNSC Resolution 2249 as allowing for or facilitating in any a way the exercise of a right to self-defence. Nowhere in this document reference is made to this concept, not even implicitly. It has been suggested that the reference in paragraph 1 of UNSC Resolution 2249 to 'the capability and intention [of ISIS] to carry out further attacks' should be read as an authoritative confirmation of the "immediacy" element required to permit a response in terms of self-defence. ${ }^{23}$ As will be seen later on, this view does not withstand closer scrutiny.

In the past, before 11 September 2001 the fight against terrorism was primarily seen as a question of national law enforcement, ${ }^{24}$ even though

\footnotetext{
${ }^{22}$ Interestingly enough, not only academics but also Foreign Offices had problems in interpreting this Resolution. The United Kingdom, for example, relied primarily on collective self-defence according to Article 51 of the Charter to justify military action in Syria. Resolution 2249 was only seen as a clarifying instrument with regard to the factual circumstances and as a reinforcing (but not an independent) basis as to Article 51. See, M Milanovic, How the Ambiguity of Resolution 2249 Does Its Work <http://www.ejiltalk. org/how-the-ambiguity-of-resolution-2249-does-its-work/> (13 December 2015). For an extensive discussion of this question, see also, R Ruys \& L Ferro, Divergent Views on the Content and Relevance of the Jus ad Bellum in Europe and the United States? The Case of the U.S.-Led Military Coalition against'Islamic Staté <http:// papers.ssrn.com/sol3 / papers.cfm?abstract_id=2731597\&download=yes > (16 February 2016).

${ }^{23}$ See, Weller supra note 3. As is well known, the immediacy requirement results very clearly from the Webster-formula in the Caroline case. See, Correspondence between Great Britain and the United States, respecting the Destruction of the Caroline, 26 British \& Foreign State Papers (1837-1838) 1372-1377; 29 British \& Foreign State Papers (1840-1841) 1126-1142; 30 British \& Foreign State Papers (1841-1842) 193-202.

${ }^{24}$ See, MN Schmitt, U.S. Security Strategies: A Legal Assessment, 27 Harvard J L \& Pub Policy (2003-2004) 737,746 . The term "terrorism" itself was much contested as a legal term of international law. For Rosalynn Higgins, this was a "term of convenience" with "no specific legal meaning." See, R Higgins, The General International Law of Terrorism, in, R Higgins \& M Flory (eds) Terrorism and International Law (Routledge, London, 1997) 27. Some scholars questioned the propriety of a distinction between traditional (national) and modern (international) forms of terrorism. See, L Van den Herik \& N Schrijver, The Fragmented International Legal Response to Terrorism, in, van den Herik \& Schrijver (eds) Counter-Terrorism Strategies in a Fragmented International Legal Order (CUP, Cambridge, 2013) 1 [7] referring to V Low, Security Concerns and National Sovereignty in the Age of World-Wide Terrorism, in, J MacDonald \& DM Johnston (eds) Towards World Constitutionalism(M Nijhoff Publishers, Leiden, 2005) 656-659.
} 
trans-border actions did occur. Terrorists were treated as pure criminals; the international element in this fight was more or less confined to transnational police cooperation. ${ }^{25}$ As to international measures in the stricter sense, state attitude depended on the specific circumstances. In the face of attacks by terrorist groups with international connections, the reactions regularly bore some international elements but there were no consistent and coherent traits. The bombing of Pan Am flight 103 over Lockerbie in 1988 that killed 270 people did not lead to military measures but rather to prosecution in the Netherlands under British law, ${ }^{26}$ although initially forceful measures were considered as an option. In some situations, however, armed responses followed. This was the case in 1986 when Libyan agents bombed a Berlin discothèque provoking American air strikes in Bengasi and Tripoli. The same holds true also for the attacks on the US embassies in Nairobi and Dar es Salam in August 1998 that killed and wounded hundreds of people. Here, the US responded by missile attacks on alleged terrorist camps in Afghanistan and on a pharmaceutical plant in Khartoum that served as a bomb factory according to US intelligence source. Israel and Turkey had for many years advanced the self-defence argument for their military operations against Palestinian and Kurd fighters. ${ }^{27}$ Overall, these justifications met, however, with strong opposition by the international community or, at best, they were ignored. The self-defence argument was therefore far from being generally accepted. ${ }^{28}$

The attacks on the Twin towers of 2001 changed all this. At least this was the first impression that came to mind when the UNSC adopted Resolution 1368 a day after the attack, on 12 September 2001. In its preambular part, this resolution refers indirectly to Chapter VII when it voices its determination 'to combat by all means threats to international peace and security' and expressly to the inherent right of individual and

\footnotetext{
${ }^{25}$ It has been suggested that this is the way the terrorist problem should in the first place be dealt with still today. M Wood, Terrorism and the International Law on the Use of Force, in, B Saul (ed), Research Handbook on International Law and Terrorism (Edward Elgar, Cheltenham, 2014) 195, 196 'The actions of terrorist groups are properly treated as crimes under the internal laws of various states. Events on a scale like those of $9 / 11$, which may qualify as armed attacks for the purposes of the jus ad bellum, are the exception.'

${ }^{26}$ Schmitt, supra note 24,746 . There is, up to this moment, no true international criminal justice for terrorists. The Rome Statute does not apply to terrorism and no attempts can be discerned for amendments going in this direction. See, N Schrijver \& L van den Herik, Leiden Policy Recommendations on Counterterrorism and International Law (2010) 4 <http://www.grotiuscentre.org/resources/1/Leiden\%20Policy\% 20Recommendations\%201\%20April\%202010.pdf $>$. According to these Recommendations terrorism should be primarily dealt with at the level of national criminal justice and to this end they argue i.a. for the criminalization of more terrorist acts and for more effective transnational cooperation. Ibid 9.

27 For an overview on these facts, see, L Moir, Reappraising the Resort to Force supra note 6, $140 \mathrm{ff}$.

${ }^{28}$ See also, C Focarelli, Trattato di diritto internazionale (UTET, 2015) 1801 [263]; L Moir, ibid 22 ff.
} 
collective self-defence in accordance with the Charter, and therefore to Article 51 of the Charter without mentioning this provision. A similar position was echoed in Resolution 1373 of 28 September 2001. ${ }^{29}$ Equivocal as these statements were, they were afterwards read as the first official pronouncement by the UNSC Security Council as to the application of the right to self-defence also against terrorist groups. ${ }^{30}$ When asked how these statements should fit into the existing international legal order and what this should mean on the practical level, legal interpreters seemed puzzled. There was a strong opinion in literature that the statements in Resolution 1368 and 1373 of 2001 were of an outspoken emotional character due to the nature and the impact of the attacks of $9 / 11$ and that no new legal ground had been broken. ${ }^{31}$ And in fact, for more than a decade, the UN Security Council did not take up again this approach with regard to other situations of terrorist attacks. The question whether self-defence was allowed with regard to terrorist attacks had therefore to be answered on the basis of general international law, and, in particular, with reference to inter-state relations. This proved to be a daunting task.

As a matter of fact, Article 51 of the UN Charter applies also to terrorist attacks. ${ }^{32}$ But for a long time this provision has been primarily read under the perspective of state responsibility, an approach that led in several cases to awkward, not to say aberrant solutions. The leading-and often also misleading - case is the Nicaragua case decided by the International Court of Justice (ICJ) in 1986. There the ICJ stated the following:

$[T]$ the prohibition of armed attacks may apply to the sending by a State of armed bands to the territory of another State, if such an operation, because of its scale and effects, would have been classified as an armed attack rather than as a mere frontier incident had it been carried out by regular armed forces. ${ }^{33}$

29 See, the fourth preambular paragraph of Resolution 1373 recognizing "the inherent right of individual or collective self-defence as recognized by the Charter of the United Nations as reiterated in resolution 1368(200).

${ }^{30}$ For an early proposition see, T Franck, Terrorism and the Right to Self-Defense, 95 American J Intl $L$ (2016) 839. See also, A Bianchi, Enforcing international law norms against terrorism (Hart, London/Portland 2004).

31 As to the exceptional character of this Resolution see A Roberts, Afghanistan and International Security, 85 Intl L Stud (2009) 3 [15]; E Keynes, in, I-J Werkner \& ors (eds) Der ambivalente Frieden: Die Friedensforschung vor neuen Herausforderungen (VS Verlag, 2011) 232 'Resolution 1368 is, from my perspective, to say the very least, vague. It authorizes everything and nothing at the same time'.

${ }^{32}$ As it seems, only a minority in academia contests this proposition. Among them, see, A Pellet, Non, ce n'est past la guerre, Le Monde (20 September 2001); E Myler \& N White, The Twin Towers attack: An Unlimited Right to Self-Defence, 7 J Conf \& Security L (2002) 5; O Schachter, The Use of Force against Terrorists in Another Country, 19 Israel Yrbk Hum Rts (1989) 209. For a recent critical stance in this regard, see also, O Corten, The Law against War (Hart Publishing, Oxford, 2010) $160 \mathrm{ff}$.

33 Military and Paramilitary Activities (Nicaragua v US) [1986] ICJ Rep 14, 103. 
The ICJ is adopting here a traditional, conservative logic. First of all, the acts by "armed bands" must be attributable to another State (and in this regard a very high and therefore much criticized threshold is applied). Secondly, a considerable intensity is required for such an attack to qualify as an armed attack. In other words, for Article 51 to apply in the face of such activities the dimension of the military measures must be the same as in the case of an attack by a State and behind these activities there must again be a state. ${ }^{34}$

This pronouncement left important questions unaddressed, thereby creating the misleading impression that all these situations would automatically be excluded from the purview of Article 51. Unfortunately, in two subsequent cases the ICJ missed the opportunity to clarify this issue. In the Wall Opinion of 2004 the ICJ would have had the unique chance to bring clarity to this subject as the self-defence argument with regard to non-state actors was explicitly advanced by Israel. In a highly convoluted and sketchy paragraph, the ICJ, however, came to the conclusion that Israel could not justify the building of the wall by invoking Article 51 as Israel had not been able to impute the attacks to a foreign state or to an external threat to which UNSC Resolutions 1368 and 1373 referred. ${ }^{35}$

As it appears, this case was so highly contentious and politically charged that the ICJ sought a way out that proved to be technically a really fortunate one. Again, however, the false impression was created that Article 51 applied only to inter-state relations. ${ }^{36}$ One year later, the ICJ again dodged this question by giving on the one hand the

\footnotetext{
34 This very restrictive attitude met with harsh criticism both in practice as in literature. As is wellknown, one of the most outspoken critics of this approach was dissenting Judge Schwebel who said 'In short, the Court appears to offer-quite gratuitously-a prescription for overthrow of weaker governments by predatory governments while denying potential victims what in some cases may be their only hope of survival.' Dissenting Opinion of Judge Schwebel, Military and Paramilitary Activities, ibid [177]. See also, Dissenting Opinion of Judge Jennings, ibid 543. Strong criticism against this approach was raised by Rosalynn Higgins who famously said 'Is the question of level of violence by regular forces not really an issue of proportionality rather than a question of determining what is an "armed attack"?'. See, R Higgins, Problems and Process: International Law (OUP, Oxford,1994) 251. A far more favourable view as to the correspondence of the "Nicaragua formula" with customary International Law was expressed by C Gray, International Law and the Use of Force (OUP, Oxford, 2008) $130 \mathrm{ff}$.

${ }^{35}$ See, Legal Consequences of the Construction of a Wall in the Occupied Palestinian Territory, Advisory Opinion [2004] ICJ Rep [139].

${ }^{36}$ It shall not go unmentioned, however, that several authors tried to offer a more positive reading of these findings by the ICJ. According to Kimberley N Trapp there is 'an alternative interpretation of the Court's decisions, informed by judicial economy, which does not condition the right to use defensive force in reliance on Article 51 of the UN Charter on the attributability of an armed attack.' These pronouncements should not be read as statements of a general rule but rather be seen in close connection with the specific factual situation. See, KN Trapp, Can Non-State Actors Mount an Armed Attack?, in, M Weller (ed) The Use of Force in International Law (OUP, Oxford, 2015) 679, 686. According to Christine Gray the Court was even 'well advised to avoid pronouncing on such a controversial topic when this was not absolutely necessary for its decision....' See, C Gray, The International Court of Justice and the Use of Force, in, CJ Tams \& J Sloan (eds) The Development of International Law by the International Court of Justice (OUP, Oxford, 2013) 237, 260.
} 
impression that it still stuck to a strict reading of the Nicaragua pronouncement while on the other hand admitting that it left open the question whether self-defence was allowed against large-scale attacks by irregular forces. ${ }^{37}$ One door was closed and the other opened and the interpretation of Article 51 was left where it stood before. ${ }^{38}$

Needless to say that the fundamental problem in this regard lies in the fact that terrorists do not reside in sovereignty-free areas. As soon as they operate internationally, at least one further sovereign state order is - at least implicitly-involved. If terrorists act as agents of this other order, the Nicaragua formula can apply without problem but the real difficulties arise as soon as such a relationship cannot be proved. State practice has developed the concept of the "harbouring state," a state giving shelter to terrorists and therefore engaging in some sort of complicity. ${ }^{39}$ This may be something less than "sending armed groups" but nonetheless these states engage responsibility. Armed response to terrorist attacks may be justified if all other criteria, in particular proportionality, is adhered to. In this context, reference has also been made to the idea of "aiding and abetting," a criterion borrowed from international criminal law. ${ }^{40}$ It can be noticed that these approaches, although remaining within the realm of state responsibility as devised by the ICJ in the Nicaragua case, considerably soften the criteria for attribution. With terrorist attacks gaining ever more destructive power state interests have to be rebalanced taking into due account also the interests of individuals.

In some senses, this rebalancing is conducive to a sliding slope. The standard for attribution immediately below that of "aiding and abetting" is that of the state "unwilling or unable" to fight terrorists effectively permitting thereby these groups, directly or indirectly, to use the respective state territory as a basis for international terrorist attacks.

\footnotetext{
37 Armed Activities on the Territory of the Congo (Democratic Republic of the Congo v Uganda) [2005] ICJ Rep [146-147].

38 The lack of clearness by the ICJ at the same time salvages its reputation as the relevant statement, with some good will, are open also for different interpretations. Any criticism against these pronouncements, if it wants to be fair, has therefore to be conditional. This consideration is very well captured by the following remark by Michael Wood: 'Insofar as the Court may have suggested there was no [right to self-defence against non-state actors] its views were not well founded in state practice and have not been followed by states since 9/11.' See, M Wood, Terrorism and the International Law on the Use of Force, in, B Saul (ed) Research Handbook on International Law and Terrorism (Edward Elgar Cheltenham, 2014) 195, 201.

39 This was the case for Israel military operations in Lebanon and Syria carried out in the years after 2001 against Herzbollah and Islamic States. Israel referred to the self-defence argument sustaining that Lebanon and Syria (as well as Iran) "supported and encouraged" these terrorist groupings. See, Moir, supra note 6, 141.

40 See, C Tams, The Use of Force against Terrorists, 20 Euro J Intl L (2009) 359, 386, referring to a "more lenient standard of attribution."
} 
Here the state, out of whose territory the terrorists operate, is no longer a "harbouring" state but simply a "host state." Should self-defence be permissible also in this case? An answer pointing forcefully in the positive was given to this question by the Legal Advisor to the State Department under the Bush Administration:

[A] state must prevent terrorists from using its territory as a base for launching attacks. As a legal matter, where a state is unwilling or unable to do so, it may be lawful for the targeted state to use military force in self-defence to address that threat. ${ }^{41}$

Here we are one step in ("unwilling") and one step out ("unable") of the attribution approach. A military response should therefore be possible even if the attitude of the country from which the terrorist attacks are launched is irreproachable. In literature, doubts were expressed, however, whether the "unwilling or unable"-criterion, so forcefully advocated by the United States after 9/11, already constituted customary international law. In fact, when Russia attacked Chechen rebel forces in Georgia declaring that the host state was "unwilling or unable" to prevent terrorist activities going out from her territory, the US staunchly opposed this justification. ${ }^{42}$

Now we have to ask at what stage this legal development is at present. The inconsistency of the claims and statements referred to above does not, as such, prove much as in such a delicate area political considerations will always interfere with neutral long-term considerations. Some authoritative research and policy papers issued between 2005 and 2012, the Chatham House Principles ${ }^{43}$, the Leiden Policy Recommendations $^{44}$ and the Principles on 'Self Defence against an Imminent or Actual Armed Attack by the Non-State Actors' (the socalled "Bethlehem Principles") ${ }^{45}$, suggest that we are already at a point where a fully-fledged right to self-defense against terrorist attacks

\footnotetext{
${ }^{41}$ See, J Bellinger, Armed Conflict with Al Qaida?, Opinio Juris < http://opiniojuris.org/2007/01/15/ armed-conflict-with-al-qaida/ $>$. The same approach was taken by his successor HH Koh. See, S Ratner, SelfDefence against Terrorists: The Meaning of Armed Attack, in, L van den Henrik \& N Schrijver (eds), supra note $24,334,345$. In substance, this approach was followed also by Judge Kooijmanns and Judge Simma in their Separate Opinions. See, Separate Opinion of Judge Kooijmans, in, Armed Activities on the Territory of the Congo (Democratic Republic of the Congo v Uganda) [2005] ICJ Rep 168, 306. As Judge Kooijmanns has stated, it 'would be unreasonable to deny the attacked State the right to self-defence merely because there is no attacker State and the Charter does not so require.' Ibid 314 [30]. See, Separate opinion of Judge Simma. Ibid, 334

42 See, Gray, supra note 34, 231.

${ }^{43}$ See, E Wilmhurst, Principles of International Law on the Use of Force by States In Self-Defence, Chatham House Working Papers (2005) <https://www.chathamhouse.org/publications/papers/view/ $108106>$.

44 See generally, Leiden Policy Recommendations, supra note 26

45 See, D Betlehem, Self-Defense against an Imminent or Actual Armed Attack by Nonstate Actors, 106 American J Intl L (2012) 770.
} 
exists. ${ }^{46}$ Thus, for example, Chatham House principle no. 6 states that 'the right to use force in self-defence is an inherent right and is not dependent upon any prior breach of international law by the State in the territory of which defensive force is used.' The Leiden Policy Recommendations expressly side with the "unwilling or unable" approach $^{47}$ and this is also the case for the Betlehem principles. ${ }^{48}$

These principles, though well-respected their authors may be, are not binding international legal rules. They nevertheless convey a sentiment that is gaining more and more hold within the academic community. For some international lawyers now a customary international law rule exists according to which self-defence is permissible also against nonstate actors whose acts are not attributable to a state. ${ }^{49}$ UNSC Resolution 2249 forcefully strengthens this view.

\section{The specific characteristics of self-defence against terrorism}

In default of specific provisions in the UN Charter on how to tackle threats like those stemming from modern international terrorism the criteria developed by the ICJ on permissible self-defence between states, by and large, have been extended also to the fight against terrorism. With some of these criteria already highly contested in the inter-state context their application to non-state actors should lead to aberrant conclusions in particular if no attribution to states was possible. This becomes evident already if we look at the time factor, the request that the threat of an attack should be immediate. As is well known, the time factor is of decisive importance for assessing the legality of self-defence measures.

The wording of Article 51 of the UN Charter seems to require that an attack has already occurred. Legal interpreters, often referring to the Webster-formula of the Caroline case, ${ }^{50}$ argue that self-defence is legal if an armed attack is "imminent". Anticipatory self-defence, against a threat that has not yet fully materialized, is recently considered to be inadmissible. In practice, these notions are, however, hard to

\footnotetext{
46 See also, P Hilpold, The Applicability of Article 51 UN Charter to Asymmetric Wars, in, H-J Heintze $\&$ P Theilbörger (eds) From Cold War to Cyber War (Springer, 2016) 127.

47 Ibid 12 [32].

48 Principles 11 and 12; See, Betlehem, supra note 45, 770.

49 See, KN Trapp, Can Non-State Actors Mount an Armed Attack?, in, Weller, supra note 36, 679, 696. Doubts are, however, advanced in this regard by Carlo Focarelli. See, C Focarelli, Trattato di diritto internazionale, supra note 28, 1801[263].

50 See, supra note 23.
} 
distinguish. It is in particular not easy to state when the condition for "imminence" is met. It is therefore doubtful whether these considerations can find application in the context of the fight against terrorism, or, respectively, whether this criterion finds application in this context at all. It was said that UNSC Resolution 2249 created a situation of 'permanent imminence of the threat' and that '[i]n confirming that ISIL represent a permanent and active threat of further attack, the Council appears to relieve individual states from having to fulfil the criteria for self-defence when considering armed action in Syria. ${ }^{51}$

This is surely an ingenious proposition but in the context of the fight against terrorism it is not really useful or convincing. In fact, the criterion of "immediacy" has been introduced in order to make sure that between states (unilateral) recourse to force is taken resort to only under absolute exceptional and strictly limited circumstances. In all other cases, impending attacks should be ward off by taking recourse to one of the many instruments the Charter offers in the field of peaceful settlement of disputes or by multilateral measures ordered (or authorized) by the Security Council. The far-reaching prohibition of the use of force applying between states is closely related with respect of sovereign equality. No such respect is due towards terrorists. They may wield power equal to that of a state but legally they are not at the same level and they should never become. There is no need to restrict self-defence to an "immediate" threat of an attack by terrorists as, with the exception of human rights or humanitarian law, no restriction or "peace clause" applies towards terrorists. Only if their acts can be attributed to a State again the general rules-requiring utmost respect for state sovereignty—apply.

Similar considerations apply with regard to the so-called gravity test. In literature, much confusion reigns also in this regard. While many analysts contend that an attack has to be large scale in order to generate a right to self-defence, ${ }^{52}$ such a requirement is commonly set for an attack by an armed band or terrorists. The motive for this is usually sought in the Nicaragua judgment, but erroneously, as has been demonstrated in literature. ${ }^{53}$ In fact, there is no reason to require that

\footnotetext{
51 See, Weller, supra note 3.

52 See, 6 Chatham House Principle, 13, as well as the Leiden Policy Recommendations, supra note 26, [39].

53 As Steve Ratner demonstrates, this criterion developed by the ICJ in the Nicaragua case referred to the UNGA Definition of Aggression (UNGA Resolution 3314 of 1974) which, when discussing acts by armed bands qualifies acts by terrorists as aggression if they are 'of such gravity as to amount to the acts listed above.' He therefore rightly states that the aggression by non-state actors in order to qualify as aggression must be of the same gravity as that of states (and not higher).
} 
acts of terrorists should be of higher gravity than that of states in order to qualify as aggression. ${ }^{54}$ While it may be reasonable to pretend the same amount of gravity if terrorists act as agents of a state, the fight against terrorists with no such relationship to a state should not be made dependent upon such gravity of the acts committed. As demonstrated above, there is no need to show restraint of whatsoever kind against terrorists. ${ }^{55}$ Prudence is needed only insofar as the sovereignty of the hosting state has to be respected. In this regard, however, respect of the proportionality criterion should be sufficient in order to make sure that state sovereignty is adequately respected. It has also been said that there was the risk that forceful measures against terrorism, due to their punitive and deterrent character they often evidence, could re-introduce the concept of armed reprisals the outlawing of which was such an important achievement in the development of international law. ${ }^{56}$

Once again, there is the peril of confusing different levels of international law. While between states armed reprisals have to be strictly outlawed if the UN peace order based on the prohibition of the use of force is to be preserved, no such containment is called for in the struggle against terrorism. Terrorists, or, respectively, terrorist groups are not bearers of sovereign rights and even less they become part of a system of sovereign equality. To fight them does not endanger the peace order, quite the contrary. Often, when forceful countermeasures against terrorist acts are taken, rhetoric and timeframe, with action and counter-action often widely separated in time, may call to mind interstate reprisals but legally the situation is a totally different one. While punitive measures against states are outlawed also because alternative dispute settlement procedures are available, this is not true for the fight against terrorists. In this sense, this struggle is also far more archaic and resembles that between states (or, even before the creation of states, between rivalling entities) in ancient times.

A last brief consideration has also to be given to the question whether the fragile nature of the Syrian state broadens the scope for any possible intervention. This question has to be answered in the negative. Syria has an internationally recognized government and even if government

\footnotetext{
54 Ibid.

55 See, generally, JJ Paust, Self-Defense Targetings of Non-State Actors and Permissibility of US Use of Drones in Pakistan, $19 \mathrm{~J}$ Transntnl L \& Pol (2010) 237.

56 See, A Bianchi, The International Regulation of the Use of Force: The Politics of Interpretative Method, in, L van den Herik \& N Schrijver, supra note 24, 283,308.
} 
troops have withdrawn from many regions and are embattled in others state sovereignty is still in place and foreign intervention is prohibited without authorization by the government or the UN Security Council. In an argumentum de minore ad maius it should be remembered that the use of force is even prohibited against de facto regimes or failed states. ${ }^{57}$

UNSC Resolution 2249 has set the course for the direction future interventions in Syria can take: they are geographically limited to a certain region, they have been confined to certain addressees and they must not infringe Syrian sovereignty. This last condition does not result explicitly from UNSC Resolution 2249, but reference to the need that measures be taken in compliance with international law, in particular with the UN Charter, has clearly to be read in this light. ${ }^{58}$

\section{Conclusions: moving from a Hobbesian perspective to a Kantian one}

We can now bring the two strings developed in this paper together: UNSC Resolution 2249 is at the same time innovative and an expression of a longer term legal developments that started in 2001. This resolution gives comprehensive expression to Chapter VII, both with regard to the first articles of this Charter (Articles 39-42) as with regard to the last one (Article 51). The power to use force against terrorists is further developed, as it is the case with the right to self-defence.

UNSC Resolution 2249 is neither to be seen as a resolution of pure authorization nor primarily as a document specifying the criteria for self-defence in a specific case. This resolution lies somewhere in between and addresses Chapter VII as a whole. States fighting ISIS are defending themselves but also the international community as a whole and for this they are called upon to act. As shown, UN practice has

\footnotetext{
57 This can be deduced from the following statement in the 'Friendly Relations Declaration: Every State likewise has the duty to refrain from the threat or use of force to violate international lines of demarcation, such as armistice lines, established by or pursuant to an international agreement to which it is a party or which it is otherwise bound to respect.' See J Frowein, De facto Regime, in, Max Planck Encyclopaedia of Public Intl L (OUP, 2013) [4].

${ }^{58}$ It shall not go unmentioned that also other readings of these specific provisions have been proposed. So it was written by Akande, supra note 2, that reference to compliance with international law and particularly reference to the UN Charter suggested that the Council was not intending to confer a right not otherwise present. This reading does not seem convincing. In fact, even without this cautioning, SC action would have to obey international law as well as, in particular, the Charter. On the other hand, SC measures serve to activate powers otherwise only generally provided for in the Charter and not finding automatic application. SC authorizations may never be granted in violation of the Charter, but nonetheless they are necessary for enforcement measures according to Chapter VII to be taken.
} 
evidenced considerable flexibility in the application of the Chapter VII provisions. ${ }^{59}$ It can be argued that Resolution 2249 adds a new approach if the fight against terrorists such as ISIL is at issue.

At the same time, UNSC Resolution 2249 pays due regard to state sovereignty. Intervention is allowed only with regard to a circumscribed geographic area and in relation to clearly identified groups. On the basis of UNSC Resolution 2249 military intervention should be possible only on request or at least in cooperation with the Syrian government. ${ }^{60}$ Cooperation and coordination is also required between the interveners. If the conflict in Syria is considered to be a civil war only an intervention on invitation (or at least toleration) by the legitimate government (whatever its democratic credentials may be) is permissible. The concept of negative neutrality proposed by some lawyers in the aftermath of WWII as guiding principle for civil war intervention surely no longer applies to situations where the fight against terrorists is at issue. ${ }^{61}$ There is no neutrality in the fight against terrorists. ${ }^{62}$ The paradox resulting from these developments is that, contrary to long held fears, state sovereignty is not weakened if stronger measures against terrorists are allowed. The need to respond to an extraordinary challenge as the fight against international terrorism, has brought about this remarkable result. A few years ago, fears were voiced that a more extensive transnational use of force in the fight against international terrorism would transform Grotian international society into a Hobbesian order, in which obsession for security would lead to the violation of pivotal international agreements on which our present international legal order rests. ${ }^{63}$

\footnotetext{
${ }^{59}$ See also, C Carletti, La dimensione preventiva del contrasto al terrorismo e la protezione internazionale dell'individuo, in, A Lanciotti \& A Tanzi (ed) Uso della Forza e Legittima Difesa nel Diritto Internazionale Contemporaneo (Jovene Editore, Napoli, 2012) 283, 327, citing the Declaration of the President of the Council on The Responsibility of the Security Council in the Maintenance of Peace and Security, Doc. S/23500, 31 January 1992: 'the absence of war and military conflicts amongst States does not in itself ensure international peace and security.'

${ }^{60}$ The "Scientific Service" of the German Bundestag published recently a different opinion stating that Resolution 2249 permitted forceful measures also without consent by the Syrian (or Iraqi) Government. See Deutscher Bundestag, Wissenschaftliche Dienste, Staatliche Selbstverteidigung gegen Terroristen, WD 2 $3000-203 / 15,201515$. For the reasons mentioned, this is, however, unconvincing. This would be a clear breach of Syrian sovereignty and would most probably also contrast the very aim of this Resolution.

${ }^{61}$ As is well known, according to this principle third states should keep equidistance towards all parties involved in a civil war. See on this principle GH Fox, Intervention by Invitation, in, Weller, supra note 36, $816,827$.

${ }^{62}$ P Hilpold, Terrorismus, Bündnisfall und die Frage der Neutralität <http://wirtschaftsblatt.at/home/ meinung/gastkommentare/4873657/Terrorismus-Bundnisfall-und-die-Frage-der-Neutralitaet> $>12$ December 2015).

${ }^{63}$ See, F Sperotto, The Use of Force against Terrorists: A Reply to Christian J Tams, in, 20 Euro J Intl L (2010) 1043 with reference H Bull, The Anarchical Society: A Study of Order in World Politics (Columbia Univ Press , NY, 1977) 24.
} 
UNSC Resolution 2249 seeks to demonstrate that such a development is not a necessary one. On the contrary, exactly such extraordinary challenges like international terrorism may be conducive to a more Kantian state order in which the international rules on the use of force are reformulated in order to allow for a more effective repression of such attacks according to commonly agreed rules and under the supervision of the UN. UNSC Resolution 2249 was intended both to fight international terrorism more effectively and to ensure that this happens unilaterally as unilateral action has proved to be neither effective nor conducive to a more stable international order. Contemporary international terrorism constitutes a threat that could not be anticipated in 1945 and consequently Chapter VII does not face this issue squarely. It has been shown that the flexibility the UN rules revealed already in the past ${ }^{64}$ is still in place so that UN law may adapt them to this new task without any need to change the letter of the Charter. ${ }^{65}$ As evidenced, the jus ad bellum rules developed on the basis of the UN Charter apply only partly to the fight against terrorists and for the rest they have to be adapted to a situation with largely different requisites. ${ }^{66}$ This new interpretation of the Chapter VII rules will not lead to a more anarchical international society but rather to a society that effectively repels the threat of such an anarchy.

Acknowledgments Open access funding provided by University of Innsbruck and Medical University of Innsbruck.

Open Access This article is distributed under the terms of the Creative Commons Attribution 4.0 International License (http://creativecommons.org/licenses/by/4.0/), which permits unrestricted use, distribution, and reproduction in any medium, provided you give appropriate credit to the original author(s) and the source, provide a link to the Creative Commons license, and indicate if changes were made.

\footnotetext{
${ }^{64}$ It has been noted that the original Charter scheme for the use of collective force had been framed in the inter-state context but subsequent to Resolution 678 (1990) it has almost exclusively been used to combat threats to the peace emanating from an intra-state situation. See, C Henderson, The Centrality of the United Nations Security Council in the Legal Regime Governing the Use of Force, in, ND White \& C Henderson (eds) Research Handbook on International Conflict and Security Law (Edward Elgar, Cheltenham, 2013) 120, 137.

${ }^{65}$ That no such change is needed has been authoritatively stated by the World Summit of 2005. According to the Outcome document 'the relevant provisions of the Charter are sufficient to address the full range of threats to international peace and security.' Ibid [79].

${ }^{66}$ See recently, H-J Heintze \& P Thielbürger (eds) From Cold War to Cyber War (Springer, 2016). The great challenge will be to defend the achievements in the field of jus in bello in this asymmetric struggle between states and terrorists. The fight against terrorism might appear to be a Hobbesian one but strict respect of humanitarian law guarantees also in this field the rule of law and therefore the maintenance of a Kantian perspective.
} 